\title{
Marketri parkenin üretimi, uygulaması ve diğer ahşap parkelerle karşılaştırılması üzerine bir araştırma
}

$\ddot{O} \mathbf{z}$

\author{
Bekir Cihad Bal ${ }^{*}(\mathbb{D})$, Zeynep Gündeș ${ }^{\mathbb{D}}$, Özgür $\mathrm{Koca}^{3}$ (D)
}

Geçmişten günümüze, özellikle iç mekânlarda kullanılan mobilyalarda ve zeminlerin, duvarların ve tavanların kaplanmasında ahşap esaslı malzemeler fazlaca kullanılmıştır. Ahşap malzemenin bu şekilde tercih edilmesinin önemli sebepleri, doğal bir ürün olması, kolay işlenebilmesi, ucuz olması ve kolayca tedarik edilmesidir. Zeminlerde kullanılan ahşap malzemelerde ise, özellikle aşınma ve çizilme direncinin yüksek olması, sertliğinin yüksek olması aranmaktadır. Günümüzde, masif ağaç parke, rabita, lamine parke, laminat parke ve marketri parke şeklinde birçok farklı tipte ahşap esaslı zemin döşeme malzemesi bulunmaktadır. Marketri parke, çok estetik bir görüntüye sahiptir ve diğer parkelerle karşılaştırıldığında oldukça pahalıdır. Bu nedenle, sadece yüksek gelir grubundaki tüketiciler zemin döşemesi için marketri parkeyi tercih etmektedir. Bunun yanında, çoğu tüketici marketri parke hakkında yeterli bilgiye sahip değildir. Bu çalışmada, marketri parkenin üretimi, uygulanması ve diğer ahşap parkelerle karşılaştırılması ve ayrıca Türkiye'de üretim miktarı hakkında bilgi verilmiştir. Bu amaç doğrultusunda, Türkiye'deki marketri parke üreticilerinden anket yöntemi ile bilgi toplanmıştır. Elde edilen bilgiler karşılaştırmalı olarak verilmiştir.

Anahtar Kelimeler: Marketri parke, parke çeşitleri, stil parke

\section{A research on the production, application of marquetry parquet and comparison with other wooden parquet}

\begin{abstract}
Wood-based materials have been used extensively in the past, especially in the furniture used in the interior and in the covering of floors, walls and ceilings. The main reasons for preferring this type of wood material are the natural product, easy processing, cheapness and easy procurement. Especially for wood materials that are used in the floors, high density, high abrasion resistance and scratch resistance are required. Today, there are many different kinds of wood based flooring materials in the form of solid wood parquet, floor planks, laminated parquet, laminate parquet and marquetry parquet. The marquetry parquet has a very aesthetic appearance and is quite expensive compared to other parquet. For this reason, only the consumers in the high income group prefer the marquetry parquet for flooring. Besides, most consumers do not have enough knowledge about marketing parquet. In this study, the production of marquetry parquet, implementation and comparison with other parquet and has also tried to provide information about the amount of production in Turkey. For this purpose, the questionnaire information method from marquetry parquet manufacturer in Turkey was collected. The information obtained is given comparatively.
\end{abstract}

Keywords: marquetry parquet, parquet types, style parquet

Makale tarihçesi: Geliș: 04.02.2019, Kabul:28.10.2019 Yayınlanma:29.12.2019 * Sorumlu yazar: bcbal@ hotmail.com

${ }^{1}$ Kahramanmaraş Sütçü İmam Üniversitesi, Teknik Bilimler MYO, Malzeme Bölümü, Kahramanmaraş/Türkiye

${ }^{2}$ Kahramanmaraş Sütçü İmam Üniversitesi, Fen Bilimleri Enstitüsü, Kahramanmaraş/Türkiye

${ }^{3}$ Dempar Demircioğlu Ağaç Sanayi ve Dıș Ticaret A.Ș., Satıș ve Pazarlama Bölümü, Sakarya/Türkiye

Atıf: Bal B.C., Gündeş Z., Koca Ö., (2019), Marketri parkenin üretimi, uygulaması ve diğer ahşap parkelerle karşılaştırılması üzerine bir araştırma, Mobilya ve Ahşap Malzeme Araştırmaları Dergisi, 2(2), 110-119 


\section{Giriş}

Bilim ve teknolojideki gelişmelere rağmen, tarih öncesi çağlardan günümüze insan ile ahşap malzeme arasındaki ilişki devam etmiştir. İnsanoğlu, tarih öncesi çağlarda, yaşadığ 1 bölgede en kolay bulduğu kil, çakmaktaşı, ağaç, ağaç yaprakları, hayvan kemikleri ve derisi gibi sınırlı sayıdaki doğal maddelerden, günlük hayatını kolaylaştırmak için kendisine bazı el aletleri ve yaşadığı mekânlar için bazı gereçler ve hatta oda mobilyaları yapmıştır (Crochet 2004; Bal ve Kılavuz 2015). Sonraki dönemlerde, sırasıyla bakır, tunç ve demir gibi çeşitli metalleri işlemeyi öğrenmişlerdir. Yazının bulunması ile tarih çağları başlamış, medeniyet günümüze kadar hızlı bir gelişme göstermiş ve insanoğlunun kullandığı hammaddeler ve ürettiği malzemelerin çeşitliği hızla artmıştır (URL1, 2016). Ahşap malzeme diğer doğal hammaddelere göre, ucuz olması, kolay işlenebilmesi, yenilenebilir olması, ses ve 1sı yalıtım özeliklerinin iyi olması gibi bazı üstün özelliklere sahiptir. Bu özelliklerinden dolayı da birçok alanda kullanılmaktadır. Günümüzde yaklaşık olarak 10000 farklı kullanım alanının olduğu bildirilmiştir (Bozkurt ve Erdin 1997). Bu kullanım alanlarının başında mobilya üretimi, kâğıt ve karton üretimi, ahşap yapı elemanları, lambri üretimi ve yer döşemeleri gelmektedir.

Türkiye'de ahşap esaslı yer döşemelerinin türleri, özellikleri, üretim metotları, kullanım alanları ve diğer bazı özellikleri hakkında birçok araştırma mevcuttur. Örneğin, Türkiye'de döşeme parkeleri hakkında yapılan ilk bilimsel eser Berkel (1961) tarafından hazırlanmıştır. Bu çalışmada, parkenin tarihçesi, parkelerin mekanik özellikleri, parkelerin rutubetli ortamlarda çalışması, aşınmaya karşı mukavemet gibi özelliklerinin yanında, parke fabrikasyonu da incelenmiştir. Kantay ve Ekizoğlu (1988) Türkiye' de orman ürünleri endüstrisi kuruluş yerleri ve parke endüstrisi yerleri adlı çalışmada, parke endüstrisinde faaliyet gösteren işletmelerin kuruluş yerleri bakımından değerlendirilmesi yapılmıştır. Özen ve Gözeneli (1992) Türkiye'de üretilen parke cilalarının çeşitli ağaç türlerinde aşınma ve sertlik özelliklerine yaptığı etkiler başlıklı çalışmada, çeşitli ağaç türlerinden elde edilen test örnekleri üzerine uygulanan verniklerin sertlik ve aşınma özelliklerini incelemişlerdir. Akçay (1994) parke yapıştırıcıları adlı çalışmasında parke endüstrisinde kullanılan yapıştırıcıların özellikleri ve sınıflandırılması hakkında bilgiler vermiştir. Kalaycıŏlu (2001) laminat parke üretim teknolojisi başlıklı çalışmasında laminat parkenin üretimiyle ilgili önemli bazı bilgiler vermiştir. Bir diğer çalışma As (2002) tarafından ahşap parkelerde kalite testleri başlı̆̆ı altında yapılmış ve parkelerin, aşınma, çizilme, kaynar suya dayanıklılığı, sigara ateşine dayanıklılık, sertlik ve eğilme testleri gibi birçok test denenmiştir. Güngör ve Sofuoğlu (2003) tarafindan, ülkemizde yapılan parke konulu, çalışmalar ve değerlendirilmesi başlıklı bir derleme çalışma yapılmış ve o yıla kadar yapılan parke konulu çalışmalar hakkında kısa bilgiler verilmiştir. Kantay ve Güngör (2009) çok tabakalı masif parkelerde (lamine parke) üst tabakanın özellikleri, üst tabakada kullanılan kaplamaların üretimi, kurutulması ve parkenin oluşturulması hakkında bilgi verilmiştir. Kantay ve Güngör (2012) yapmış oldukları çalışmada parke çeşitleri, standartları ve üretim teknolojileri hakkında bilgi vermişlerdir. Güngör (2015) yılında farklı bir parke türü olan mantar yer karoları üzerine bir araştırma yapmış ve bu mantar karoların hangi hammaddeden üretildiği, nasıl üretildiği ve bazı özellikleri gibi konularda önemli bilgiler vermiştir. Ancak, yazarın ulaşabildiği kadarıyla, marketri parkenin üretimi ve özellikleri hakkında bilimsel bir esere rastlanmamıştır. Bu noktadan hareketle bu çalışmada, marketri parke hakkında bazı genel bilgiler ve ayrıca Türkiye'deki üretim miktarı, üretici firmalar, kullanılan ağaç türleri ve fiyatları hakkında bilgi verilmiştir. 


\section{Materyal ve Metot}

$\mathrm{Bu}$ çalışmada, masif parke çeşitlerinden birisi olan marketri parkenin genel özellikleri, üretimi, üretiminde kullanılan ağaç türleri, uygulama metotları ve Türkiye' deki üretici firmalar ve bu firmaların üretim miktarları ve satış fiyatları araştırılmıştır. Araştırmada elde edilen bilgilerin bir kısmı çeşitli internet kaynaklarından elde edilmiştir. Firmaların üretim metotları, kullandıkları ağaç türleri, satış fiyatları ve yıllık üretim miktarları gibi veriler ise her firma ile görüşülerek yapılan bir anket çalışması sonunda elde edilmiştir. Anketler sonunda elde edilen veriler, Excel programında değerlendirilmiş ve çizelge olarak bulgular ve tartışma bölümünde verilmiştir.

\section{Bulgular ve Tartışma}

\subsection{Marketri parke tanımı ve tarihçesi}

Marketri kelimesi aslında Fransızca "marqueteri” kelimesinden gelmektedir. Almanca'da ise "intarsia" kelimesine karşılık gelmektedir. Türkçe'de karşılığı "kakma" kelimesidir (URL 2, 2016). Kakma; çeşitli kaplama, fildişi, kemik, sedef, formika veya metal levhalardan kesilen çeşitli şekilleri masif tabla üzerinde açılan yuvalarına veya yüz kaplamanın uygun yerine gömmek suretiyle elde edilen kompozisyon şeklinde tanımlanmaktadır (Zorlu, 1997). Marketri parke farklı renklerdeki masif ağaç malzemenin, değişik şekillerde küçük parçalara kesilip sonra birleştirilmesi ile yapılan bir parkedir. Bu parke genelde; marketri parke, marküteri parke, saray parkesi veya sanat parke olarak isimlendirilmektedir. Kantay ve Güngör (2012) tarafindan yapılan çalışmada, parke sınıflandırmada, bu parke "Tabla Parke" şeklinde isimlendirilmiştir. Ancak, yapılan bu çalışmada, çok yaygın olarak kullanılan "marketri parke" şeklindeki ismi kullanılmıştır.

Kakmacılık mobilya elemanlarının, bazı süs eşyalarının ve özelliklede bunların görünen üst yüzeylerini süslemek için yapılan bir işlemdir. Ancak, zaman içerisinde bu teknik masif ahşaptan üretilen yer döşemelerinde de uygulanmaya başlamıştır. Marketri parke adı buradan gelmektedir.

Kakmacılık veya diğer adı ile marketri süslemenin tarihçesi çok eski dönemlere kadar gitmektedir. İlk olarak eski mısırda bu tekniğin kullanıldığ 1 belirtilmiştir (Özker 2013). Kraliçe Cleopatra'nın sarayını daha iyi süsleyebilmek için o dönemin sanatkârları tarafından yapıldığı, kraliçenin bu tarzı çok beğenmesi üzerine giderek daha çok uygulandığı bilinmektedir. Sonraki yıllarda ise Fransa, İran, Arabistan ve İtalya'ya kadar bu tarzın yayıldığı ve hatta Osmanlı imparatorluğunda marketri sanatının Fatih Sultan Mehmet Han tarafından da yapıldığı bildirilmiştir (Özker 2013; URL 3, 2016). Ancak, ilk marketri parkenin nerede uygulandığ1 ve devamında nerelerde gelişme gösterdiği hakkında yeterli bilgiye ulaşılamamıştır. İlk masif parke ise: Viyana'da "Kapuziner" manastırında kullanıldığı için eski zamanlarda "Viyana yer döşemesi” veya "Kapuziner yer döşemesi” adıyla anılmıştır (Berkel 1961).

\subsection{Marketri parke üretim şekilleri ve mekânlara uygulama metotları}

Marketri parke farklı renklere sahip masif ağaç parçaların, geçmişte basit el aletleri ile günümüzde ise lazer ile sade geometrik şekillerde, karmaşı geometrik şekillerde veya bazı çiçek, ağaç yaprak veya hayvan resimlerini yansıtacak şekilde kesilmesi ve sonra bu parçaların estetik bakımdan albeni oluşturacak şekilde yan yana birleştirilmesi ile oluşturulmaktadır. Günümüzde marketri parkenin parçalarının üretiminde, basit el aletleri, CNC makineleri veya 
lazer kesim makinelerinden yararlanılmaktadır. Marketri parke piyasaya, üzerinde simetrik desenler bulunan daire, kare veya dikdörtgen geometrilerde üretilmiş, marketri bordür, marketri göbek ve marketri karo isimleri altında sunulabilmektedir (Şekil 1). Bunun haricinde özel siparişle projesi-deseni sadece kişiye özel üretimler olarak ta yapılabilmektedir (Şekil 2). Marketri parkenin hem parçalarının üretilmesi ve hem de yerine montajı oldukça uzun zaman almaktadır. Eğer istenilen desen kişiye özel yapılıyorsa bu durumda süre daha da uzamaktadır. $\mathrm{Bu}$ şekilde üretilen marketri parkelere, saraylarda, üst düzey yöneticilerin makam odaların da, lüks otellerde, üst gelir grubu tüketicilerin villa, yalı, köşk ve malikânelerinde görülmektedir (Bal ve Gündeş, 2016).
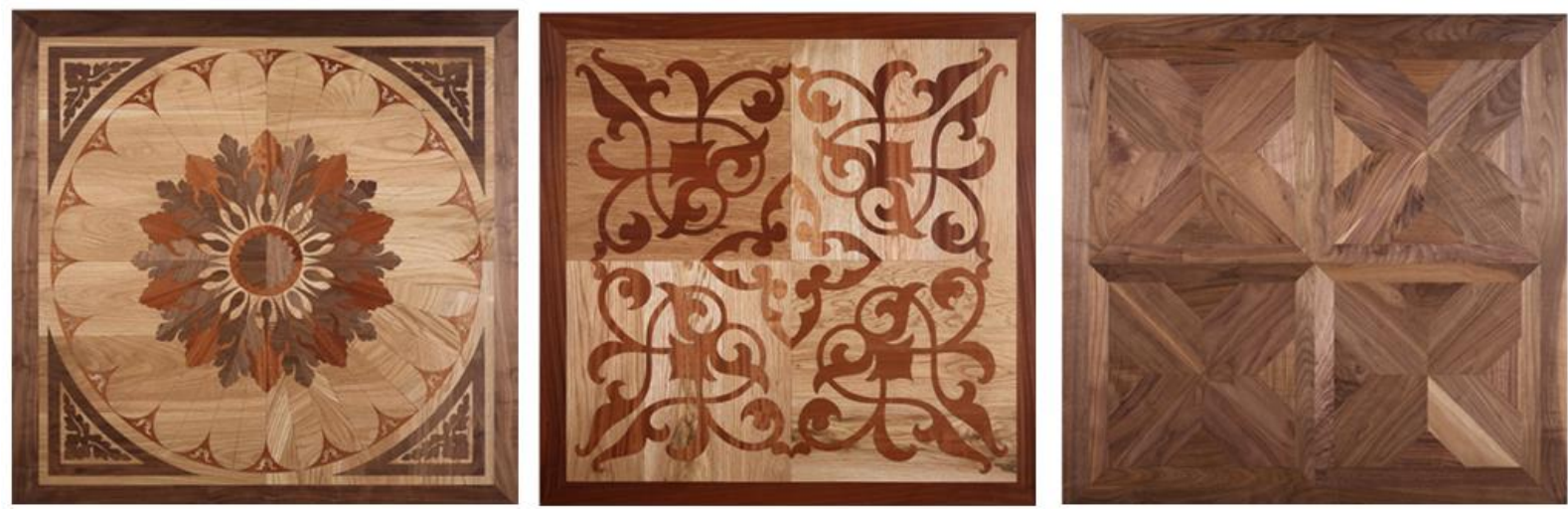

Şekil 1. Daire veya kare geometrilerde üretilmiş marketri parke örnekleri (URL 4, 2016)
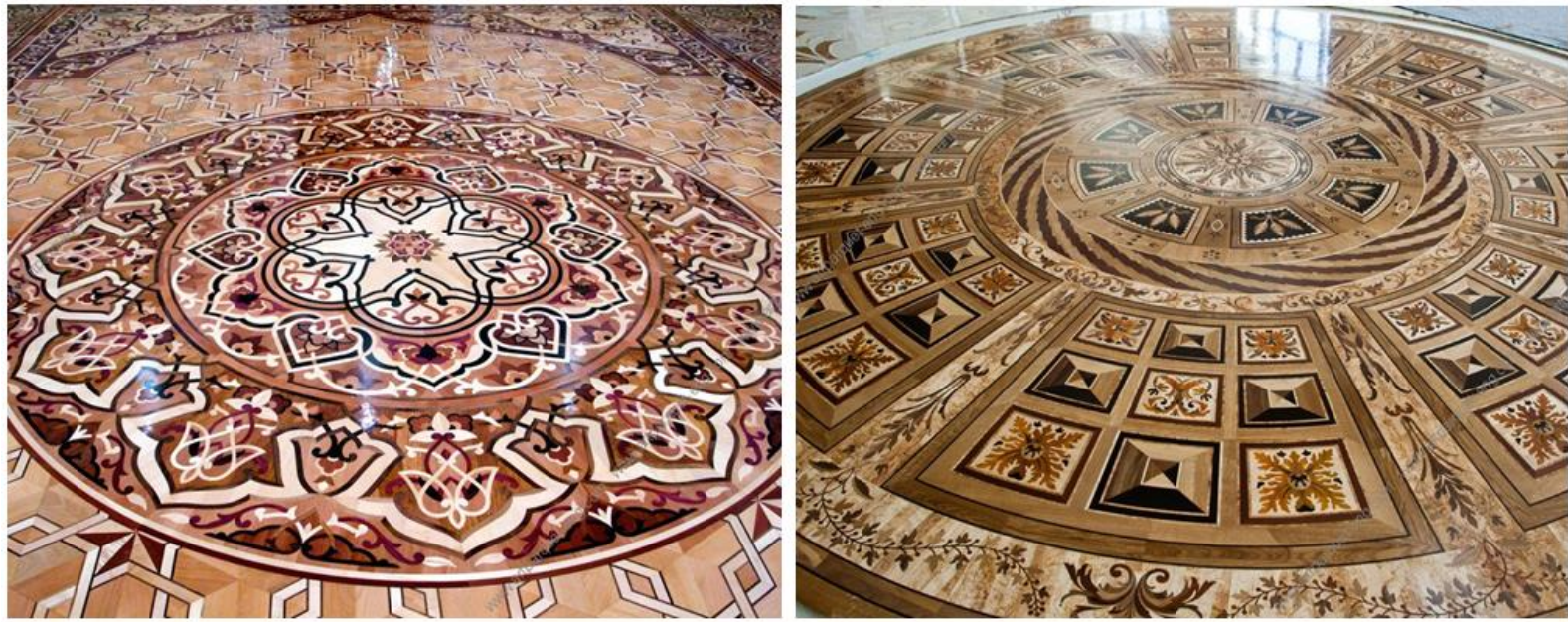

Şekil 2. Özel proje ile üretilen marketri parke örnekleri (URL 5, 2018)

Marketri parke, geçmişten günümüze 3 farklı şekilde zemine uygulanmıştır. İlk uygulamalarında, marketri parkelerin parçaları atölyelerde elle tek tek kesilerek hazırlanmış, daha sonrasında uygulanacak olan mekânların zeminlerine birbirlerine gizli bağlantılar ile birleştirilerek sabitlenmiştir. Zemine monte edilen marketri parçalarının, daha sonra zımparalanarak yüzeylerindeki tüm hataların temizlenmesi sağlanmış, sonrasında ise balmumu ile yüzeyleri parlatılmış ve zamanla değişik cilalar ile parlaklık verilmiştir. Ancak bu uygulama 
metodunun yavaşlığı ve zorluğu uygulamacıları daha pratik yöntemlerin arayışına sevk etmiştir. Sonraki uygulamalarda, marketri parkeyi oluşturan parçaların kalınlığının düşürülmesi ve buna karşılık, alt taşıyıcı elemanların keşfedilmesi hem süreci hızlandırmış, hem de marketri parkelerin dayanıklılığını, stabilitesini ve servis süresini arttırmıştır. Özellikle çok tabakalı huş kontrplak üretiminin yaygınlaşması ile marketri parke imalatında da kullanımı başlamıştır. Bu uygulamada, kontrplağın zemine serilmesi ve sabitlenmesi sağlanmış ve sonra üzerine marketri parkeyi oluşturan parçalar, ayrı ayrı tutkallar ile sabitlenmiştir.

Kontrplağın zemine serilerek kullanılmaya başlandığı uygulamalarda ise uygulamanın zorluğu ve uygulama süresinin uzun olması üreticileri yeni arayışlara yöneltmiştir. Bu arayışlar sayesinde günümüzde uygulanan marketri bloklarının (Şekil 3) üretimi metodu geliştirilmiştir. Bu bloklar, lazer kesim metodu ile hata payı sıfıra yakın oranda kesilmiş olan ağaç parçalarının daha sonra fabrikada kontrplak ile özel tutkallar kullanılarak yapıștırılması sayesinde elde edilmiştir. Daha sonra bu marketri blokları, cilalanmakta ve montaja hazır bir halde uygulama alanına sevk edilmektedir. Modüller halinde uygulama alanına getirilen marketri parkeler, zemin eğim ölçümleri yapıldıktan sonra özel tutkallar ile yere yapıştırılarak uygulanmaktadır. Bu uygulamada, montaj aşaması biter bitmez, mekânın kullanıma hazır hale gelmesi de sağlanmaktadır. Bu yöntem sayesinde, insan hataları azaltılmış, tutkal lekelenmeleri önlenmiş, montaj zamanı azaltılmış, cila zorluğu aşılmış ve böylece maliyetlerin düşürülmesi de sağlanmıştır. Bu yenilik, aynı zamanda marketri parkenin herkes için ulaşılabilir bir ürün haline getirilmesini de sağlamıştır (Bal ve Gündeş, 2016).
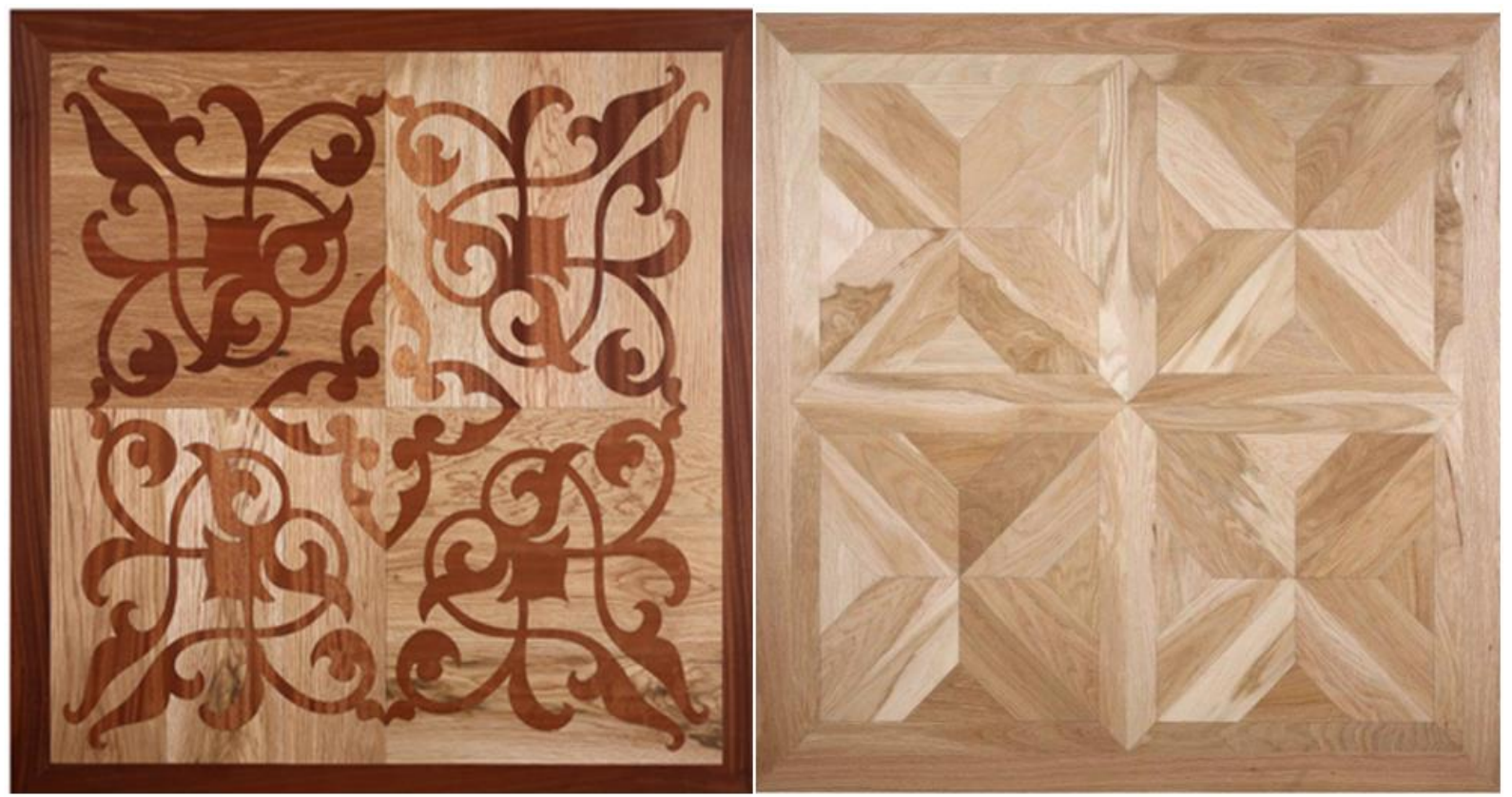

Şekil 3. Marketri parke blokları (URL 5, 2017) 


\subsection{Türkiye'de marketri parke üretim miktarları}

Türkiye'de 3 farklı şekilde marketri parke üretimi yapıldığg belirlenmiştir. Bunlar; 1tamamen masif parçalardan oluşan, 2-taşıyıcı olarak kontrplak ve üst yüzeyinde kalın ağaç papellerden oluşan, 3-taşıyıcı olarak lif levha ve üst yüzeyi papellerden oluşan marketri parkelerdir. Türkiye'de yaygın olarak tercih edilen ise taşıyıcı olarak kontrplağın kullanıldığı yöntemdir.

Türkiye'de marketri parke üretici firmalar, üretim miktarları, kullanılan ağaç türleri ve ortalama satış fiyatları aşağıda Çizelge 1'de verilmiştir. Satış yapan her firma aynı zamanda üretici değildir. Yurt içi ya da yurt dışı bazı üreticilerin hazır desenli marketri parkelerinin satışını yapmaktadırlar. Ulaşabilen bilgiler doğrultusunda, Türkiye'de en yüksek üretim miktarına sahip firma Dempar Parke'dir. Yaklaşık $22000 \mathrm{~m}^{2}$ yıllık üretim miktarına sahiptir. Satışını yaptığ 1 marketri parkelerin tamamını kendisi üretmektedir.

Marketri parke üretim miktarı ve satışı konusunda net rakamlara ulaşılamamıştır. Çizelge 1 incelendiğinde Türkiye'de marketri parke üretim ve satış miktarlarının çok yüksek miktarlarda olmadığı, hatta diğer parke türlerine göre en az tercih edilen parke olduğu söylenebilir. Yapılan araştırma sonucunda, Türkiye'de yıllık ortalama $30 \quad 000 \quad \mathrm{~m}^{2}$ marketri parke yapıldığ 1 belirlenmiştir. Satış fiyatları incelendiğinde minimum 60 Euro'dan başlayan fiyatlar verildiği ve özel işlerde 1000 Euro'nun üzerinde fiyatların olduğu görülmektedir. Laminat parkenin yaklaşık 8-10 ve lamine parkenin 30-50 Euro civarında piyasa fiyatları olduğu göz önünde bulundurulduğunda fiyatın oldukça yüksek olduğu görülmektedir. Elde edilen bilgilere göre, Türkiye'de marketri parke üreten firmaların genelde meşe, ceviz, akçaağaç, maun ve iroko türlerini tercih ettikleri görülmektedir. Bazı firmalar özellikle Amerikan ceviz türünü tercih ettiklerini belirtmişlerdir. Türkiye'de yapılan üretimlerde 5-6 farklı ağaç türü kullanıldığ 1 belirlenmiştir. Ancak, Rusya'da faaliyet gösteren ve marketri parke üreten bir firmanın 200 civarında farklı ağaç türü kullandığı, yapılan işe ve oluşturulan desenin karmaşıklığına bağlı olarak çok sayıda ağaçtan yararlanıldığı belirlenmiştir (URL 5, 2016).

Çizelge 1. Türkiye'de marketri parke üretimi ve satışı yapan bazı firmalar

\begin{tabular}{|c|c|c|c|c|}
\hline Firma adı & $\begin{array}{c}\text { Yıllık ortalama üretim } \\
\text { veya satıs miktarı }\left(\mathbf{m}^{\mathbf{2}}\right)\end{array}$ & $\begin{array}{c}\text { Ortalama } \\
\text { Fiyatlar (Euro) }\end{array}$ & $\begin{array}{c}\text { Kullanılan ağaç } \\
\text { türleri }\end{array}$ & Uygulama yerleri \\
\hline $\begin{array}{c}\text { Dempar } \\
\text { Parke }\end{array}$ & 22000 & $80-350$ & Meşe, ceviz, iroko & $\begin{array}{c}\text { Saraylar, oteller, } \\
\text { köşkler }\end{array}$ \\
\hline $\begin{array}{c}\text { Ozan } \\
\text { Parke }\end{array}$ & 2500 & 120 & $\begin{array}{c}\text { Amerikan cevizi ve } \\
\text { meşe }\end{array}$ & İş yeri ve evler \\
\hline $\begin{array}{c}\text { Istanbul } \\
\text { Parke }\end{array}$ & 2000 & $100-300$ & $\begin{array}{c}\text { Amerikan cevizi meşe, } \\
\text { akçaağaç, maun }\end{array}$ & $\begin{array}{c}\text { Devlet binaları, } \\
\text { oteller, evler }\end{array}$ \\
\hline $\begin{array}{c}\text { Güral } \\
\text { Parke }\end{array}$ & 1500 & 120 & Amerikan cevizi, meşe & İş yeri, saray, kasır \\
\hline $\begin{array}{c}\text { Daco } \\
\text { Parke }\end{array}$ & 500 & $95-150$ & Meşe & Evler \\
\hline $\begin{array}{c}\text { Burak } \\
\text { Parke }\end{array}$ & 350 & $100-1000$ & Meşe & $\begin{array}{c}\text { Makam odaları, } \\
\text { yalılar, villalar }\end{array}$ \\
\hline $\begin{array}{c}\text { Dizayn } \\
\text { Parke }\end{array}$ & 200 & Oteller, evler \\
\hline
\end{tabular}

(Çizelgede firmalar üretim miktarına göre sıralanmıştır) 


\subsection{Marketri parkenin diğer ahşap yer döşemeleri ile karşılaştırılması}

\subsubsection{Marketri parkenin tahta yer döşemesi (rabıta) ile karşılaştırılması}

Ahşap esaslı yer döşemelerinin en eskisi ve en uzun süre rağbet gören türü tahta döşeme veya bir diğer adı ile rabıtadır. Tahta yer döşemelerinin üretiminde çam ve sedir gibi özellikle iğne yapraklı ağaçların keresteleri daha çok tercih edilmiştir. Günümüzde, çoğu müşteri için yeterince estetik olmaması, döşeme işinin maliyetli olması, kullanım esnasında bazı sorunlar oluşması ve yüzeyinde kullanılan verniğin bakım istemesi gibi nedenlerle kullanımı son derece azalmıştır. Şekil 4'de tahta yer döşemesinin döşenmesine dair bir resim verilmiştir. Marketri parkeye göre fiyat bakımından oldukça caziptir. Döşemesi kolaydır. Üretim aşaması kısa sürelidir. Ancak, estetik değildir.

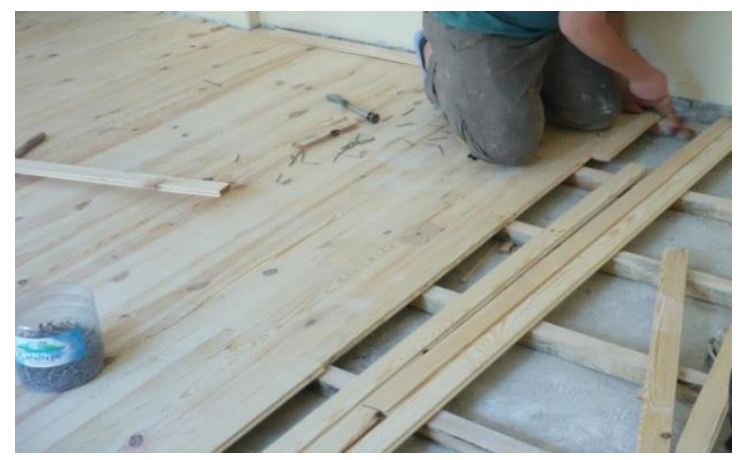

Şekil 4. Tahta yer döşemesi uygulaması (URL6, 2016)

\subsubsection{Marketri parkenin masif ağaç parke ile karşılaştırılması}

Masif parkeler kayın ve meşe gibi sert ağaçlardan, dikdörtgen şeklinde küçük parçalar şeklinde üretilmektedir. Zemine döşenirken genellikle geometrik bazı şekiller oluşturularak estetik açıdan güzel görünümler oluşturulur. Döşeme işi bittikten sonra masif parkelerin yüzeyleri verniklenir (Gürtekin ve Oğuz 2002). Fiyatının yüksek olması, kullanımı esnasında parkelerin aralarında meydana gelen açılmalar ve vernik katmanının belirli aralıklarla bakım istemesi ve estetik bulunmaması gibi nedenlerle zaman içerisinde kullanımı son derece azalmıştır. Şekil 5 'de masif parke döşeme şekilleri örnekleri verilmiştir. Masif parke marketri parke ile kıyaslandığında fiyatı çok daha düşüktür. Ancak, estetik bakımdan yetersizdir. Farklı şekiller oluşturma imkânı yoktur. Ayrıca, kullanımı esnasında ek yerlerinde açılma oluşması istenmeyen özelliklerindendir.
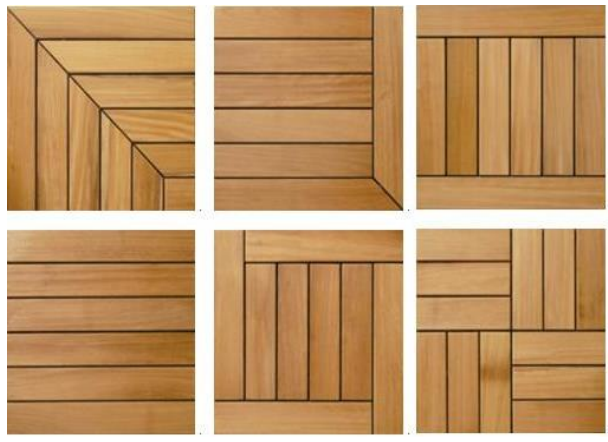

Şekil 5. Masif parke uygulamasında kullanılan bazı geometrik şekiller (URL 7, 2016) 


\subsubsection{Marketri parkenin lamine parke ile karşılaştırılması}

Lamine parke 2 veya 3 tabakalı olarak üretilebilmektedir. En üst tabakada estetik açıdan zengin görünüme sahip değerli bir ağaçtan elde edilmiş 3-4 mm kalınlığında biçme kaplama, orta tabakada yumuşak ağaçlardan elde edilmiş dar parçalar ve en alt tabakada ise yine yumuşak ağaçlardan elde edilmiş kaplama levhası birbirlerine çapraz gelecek şekilde tutkallandıktan sonra birleştirilmektedir (Kantay ve Güngör, 2009). Ayrıca, kontrplak üzerine sert ağaç kaplamaların yapıştırılması ile de lamine parke üretimi yapılmaktadır (URL 8, 2016). Döşemesi, tahta yer döşemesi ve masif parkeye göre hızlı yapılabilmektedir. Estetik açıdan bu iki yer döşemesine göre daha zengindir. Ancak, dezavantajı fiyatıdır. Tahta yer döşemesi ve masif parkeye göre yüksek maliyetinden dolayı her tüketici grubu tarafindan tercih edilememektedir. Aşağıda Şekil 6'te lamine parkenin katmanları gösterilmiştir. Marketri parke ile karşıllaştırıldığında, estetik bakımdan zayıftır. Özel yüzey şekli elde etmek mümkün değildir. Vernik ve cila gibi yüzey işlemleri bakımından marketri parke ile yaklaşık aynı yapıdadır. Ancak, fiyatı çok daha düşüktür. Türkiye'de üretimi ve ihracatı marketri parkeye göre çok daha fazladır.

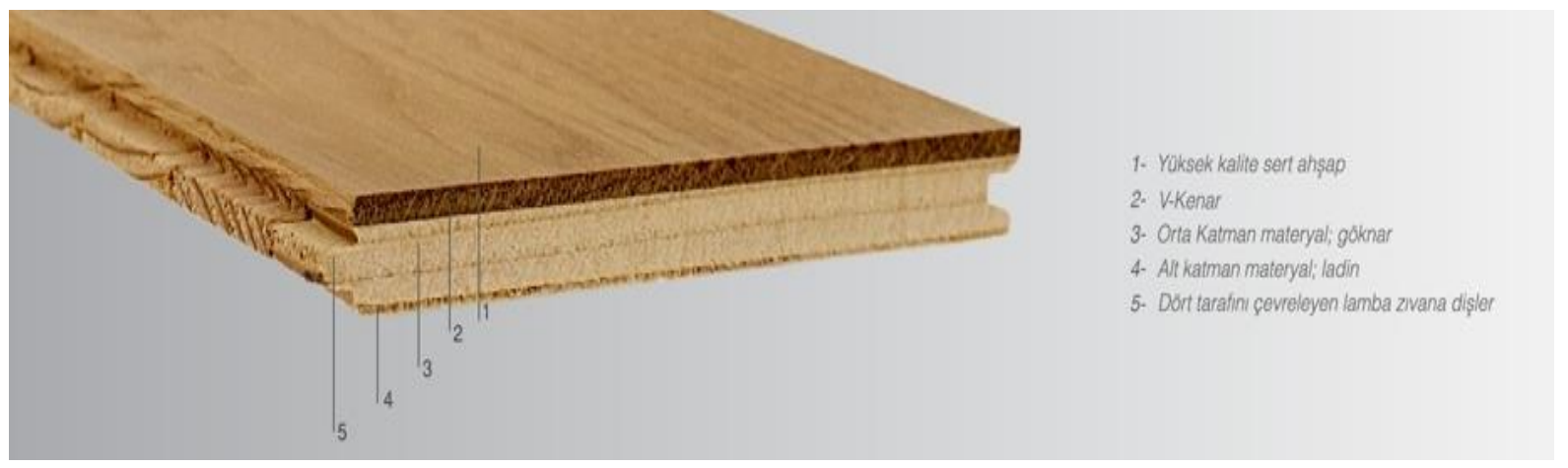

Şekil 6. Lamine parke katmanları (URL 8, 2016)

\subsubsection{Marketri parkenin Laminat Parke ile Karşıılaştırılması}

Laminat parke, en altta bir balans kâğıdı, onun üstünde HDF levha, onun üstünde de dekoratif tabaka ve overlay tabakası bulunan 4 tabakalı bir parkedir. Parkeyi oluşturan tüm tabakalar suni ürünlerdir. Ahşap esaslıdır ancak doğal değildir. Üretilmelerinde çeşitli kimyasallar kullanılmaktadır. Bu nedenle, diğer parkelere göre bazı özellikleri daha iyidir. Yüzey sertliği diğer parkelere göre yüksektir, vernik uygulamasına gerek yoktur. Kullanımı esnasında çalışma yapmaz. Montajı en hızlı yapılan ahşap esaslı parkedir. Fiyatı en düşük olan parkedir. Çok farklı yüzey desen ve renklerinde üretilmektedir. Şekil 7 'te laminat parkenin katmanlarını gösteren bir resim verilmiş̧ir.

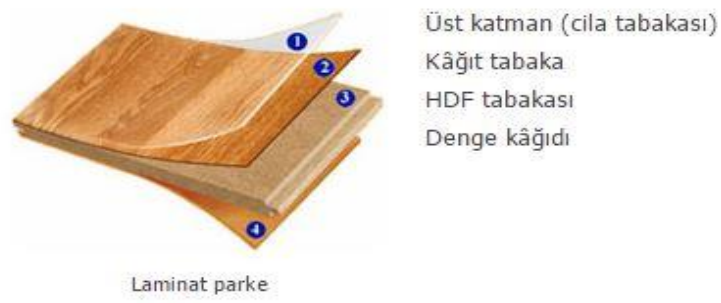

Şekil 7. Laminat parke katmanları (URL 9, 2016) 
Marketri parke ile karşılaştırıldığında, fiyatı, montaj süresi, kullanım süresinde bakım istememesi, montaj kolaylığı, sınırsız renk ve desen seçeneklerinde bulunabilmesi gibi çok sayıda üstün yönleri vardır. Ancak, laminat parke doğal bir ürün değildir. Üst yüzeyinde ve alt yüzeyinde kullanılan katmanlar suni ürünlerdir.

\section{Sonuçlar}

$\mathrm{Bu}$ çalışmada, ahşap esaslı yer döşemeleri genel gruplar halinde kısaca anlatılmış ve piyasada, diğer ahşap esaslı yer döşeme türlerine göre, çok bilinmeyen, Türkiye'de üretimi ve satışı sınırlı olan marketri parke hakkında kısa bilgi verilmiştir. Elde edilen bilgiler doğrultusunda şu sonuçlar söylenebilir;

- Marketri parkenin diğerlerine göre estetik bakımdan çok üstün olması, hatta bazı örneklerinin sanat değeri taşıması, doğal masif ağaç malzemeden yapılması gibi üstün özellikleri vardır.

- Bunun yanında, fiyatının oldukça yüksek olması, üretiminin ve montaj işçiliğinin uzun sürmesi, kullanım esnasında yıllar içersinde vernik bakımı istemesi gibi istenmeyen özelliklere sahip olduğu söylenebilir.

- İç mekânlar da çok güzel bir görüntü oluşturmasına rağmen piyasada bu parke üretici ve satıcılarının yeterli sipariş alamamalarının nedenleri; tüketiciler tarafindan yeterince tanınmıyor olması, fiyatının diğer parke türlerine göre oldukça yüksek olması, kişiye özel üretim yapılacak olduğunda uzun bir bekleme süresine ihtiyaç duyulması gibi nedenlerdir.

- Marketri parkenin maliyetinin düşürülebilmesi için, $\mathrm{CNC}$ makinelerinden daha yoğun yararlanılması, parkenin tanıtımının iyi yapılıp satış miktarının artırılması, tasarım bakımından farklılıklar oluşturarak daha düşük maliyetin sağlanabilmesi önemli geliştirme basamaklarındandır. Bu sorunlar aşılabildiği ölçüde marketri parkenin üretim ve satışının da artacağı söylenebilir.

\section{Teșekkür}

Marketri parkenin özellikleri ve Türkiye'de üretimi üzerine yapılan bu çalışmada, bizlere sağladıkları bilgiler dolayısıyla, Dempar parke, Güral parke, Daco parke, Ozan parke, İstanbul parke, Dizayn parke ve Burak parke'ye teşekkür ediyoruz. Bu çalışmanın bazı kısımları, 1st International Mediterranean Science and Engineering Congress'de (IMSEC 2016) bildiri olarak sunulmuştur.

\section{Kaynaklar}

Akçay V., (1994), Parke yapıştırıcılar, Orman Ürünleri Ahşap dergisi, 5-30.

As N., (2002), Ahşap parkelerde kalite testleri, Parke Dergisi, 2-9.

Bal, B.C., Kılavuz M., (2015), İlk mobilya, Selçuk Üniversitesi Teknik Online Dergisi, 2015 (özel say1): 56-69.

Bal, B.C., Gündeş, Z., (2016), Marketri parkenin özellikleri ve Türkiye'de üretimi üzerine bir araştırma, 1st International Mediterranean Science and Engineering Congress, 26-28 October 2016, P: 1522-1529, Adana.

Berkel, A., (1961), Döşeme parkeleri, özellikleri ve imali, İstanbul Üniversitesi, Orman Fakültesi Dergisi, 6(2): 11-37 
Bozkurt, Y., Erdin, N., (1997), Ağaç teknolojisi ders kitabı, İ.Ü. Orman Fakültesi, Yayın no: 445, S: 1, İstanbul.

Crochet, T., (2004), Designer's guide to furniture styles, pearson education. NewJersey : s:4.

Güngör, N.M., Sofuoğlu, S.D., (2004), Ülkemizde yapılan parke konulu çalışmalar ve değerlendirilmesi, Ístanbul Üniversitesi Orman Fakültesi Dergisi, 54(1), 105-114.

Güngör, N. M., (2015), Mantar yer karoları, Düzce Ün. Ormancllık Dergisi, 10(2),18-23.

Gürtekin, A., Oğuz M., (2002), Mobilya ve dekorasyon gereç bilgisi, mesleki ve teknik eğitim okulları, Milli Eğitim bakanlığı Yayınları.

Kalaycığlu, H., (2001), Laminat parke üretim teknolojisi, Parke Dekorasyon Dergisi sayı:4.

Kantay, R., Ekizoğlu, A., (1988), Türkiye'de orman ürünleri endüstrisinin kuruluş yerleri ve parke endüstrisi örneği, İTÜ ve MPM Endüstrisi Müh 88. Ulusal Kongresi.

Kantay, R., Güngör, N. M., (2009), Çok tabakalı parke üst tabaka malzemesi üretimi, İstanbul Üniversitesi Orman Fakültesi Dergisi, 59(1), 43-58.

Kantay R., Güngör N.M., (2012), Ahşap parke endüstrisi 1, parke çeşitleri, standartları, üretim teknolojileri, Ekin Yayın Grubu, İSTANBUL.

Özen, R., Gözeneli, H., (1992). Türkiye'de üretilen parke cilalarının çeşitli ağaç türlerinde aşınma ve sertlik özelliklerine yaptığı etkiler. Ormancılık Kongresi,

Özker S., (2013), Tasarımın ahşap sanatı: marküteri ve marküteri uygulaması, Mobilya Dekorasyon Dergisi, Ocak-Şubat 2013, Sayı 114, s.80-88

URL1,(2016), Tarih öncesi çağlar, http://www.tarihbilinci.com, Son erişim Tarihi: 19.09.2016.

URL2, (2016), Google translate, https://translate.google.com.tr, son erişim tarihi 24.09.2016.

URL 3, (2016), Marküteri Sanat1, http://www.unutulmussanatlar.com/2015/09/markuteri-sanat. html, son erişim tarihi: 25.09.2016.

URL 4, (2016), Dempar parke, http://www.demparparke.com.tr/ürünlerimiz, son erişim tarihi: 15.02.2018.

URL 5, (2018), Marketri parquet photos, http://artparquet-eng.com/index.php?id=gallery, Son erişim tarihi: 15.02.2018.

URL 6. (2016), Ahşap zemin döşemeleri, http://www.dekorasyonhocasi.com/yer-zeminkaplamalari/, son erişim tarihi: 22.09.2016.

URL 7, (2016), Deck döşeme, http://www.ahsapbasamak.org/dekdoseme/, Son erişim tarihi 22.06.2016.

URL 8, (2016), Lamine parke, http://www.serifoglu.com.tr, son erişim tarihi: 22.09.2016.

URL 9, (2016), Laminat parke, http://www.gncahsap.com/lamine-parke-ve-laminant-parke/, Son erişim tarihi 15.02.2018.

Zorlu, İ, (1997), Ağaç işleri konstrüksiyon bilgisi temel ders kitabı, Milli Eğitim Basım Evi, İstanbul. 